\title{
II World Literature from the Spanish-Speaking Americas
}

To better understand how Latin American literatures have been negotiated and circulated from 1959 through the present, it is worth looking at the literaryhistorical context of the Spanish-speaking Americas. ${ }^{24}$ How were literary structures developed there, and how did the poetics that were increasingly received in the context of world literature come to be? How did these reception processes unfurl, especially between Latin America and Europe? Famously, the Spanishlanguage American literatures have been perceived, since their emergence, within a tension between emancipation from and accommodation to Europe; within that tension, the pressure to adapt to trends coming out of Europe, up through the modernismo of the late 19th century, is seen as being much stronger than the emancipatory drive. Following this phase, however, a literature emerged that was increasingly received as independent and genuinely Latin American. Finally, a series of writers centered on Gabriel García Márquez and Mario Vargas Llosa became world famous during the so-called Boom in the second half of the twentieth century, and for the first time in the history of Latin American literatures, they were able to achieve overwhelming successes in the international literary market. What factors were responsible for allowing these works to achieve such clout within world literature, and in what literary-historical contexts can this kind of reception of Latin American literatures as world literature be located?

In the first part of the chapter, a critical perspective on the very fundamental and, in some cases, problematic reception pattern of emancipation and accommodation at decisive moments in the history of Latin American literatures will allow us to reevaluate these in the context of the debate over world literature. In the second part of the chapter, we will look more closely at three examples that will show to what extent the capacity of a text or body of texts to tap into particular discourses or traditions can determine reception within world literature; these examples will also allow us to develop a critical understanding of how and why other conceivable examples of world literature were not received as such.

Closely interconnected with these considerations is the fact that, from the beginnings of the Latin American literatures in colonial times, and to a certain degree up through the present, decisions about belonging to a canon were made in the publishing centers of Europe, with important publishing structures

24 See also Müller (2019a).

Ә Open Access. (C) 2021 Gesine Müller, published by De Gruyter. (c) BY-NC-ND This work is licensed under the Creative Commons Attribution-NonCommercial-NoDerivatives 4.0 International License. 
in the United States being added to that mix in the mid-20th century. Of course, we must also reflect on how those denominating centers developed over the centuries: when and where did the structures emerge that produced, or played a decisive role in determining, the reception of literary works from Latin America as world literature?

\section{II.1 A Chronological Overview of Focal Moments}

\section{Colonial Times}

Focusing on the writer Sor Juana Inés de la Cruz (approx. 1648/51-1695) in New Spain, Vittoria Borsò (2015) has undertaken a very fundamental revision of the classical reception. Even though an explicit concept of world literature was only developed after Goethe, the 17th-century Sor Juana Inés de la Cruz constituted an almost ideal type of the most important criteria for world literature, according to Borsò's thesis, which she then expands using five criteria. First of all, Sor Juana connects the particular and the universal. In her work, she relates Greco-Latin traditions and Spanish and European philosophical approaches, in particular, to local Latin American cultures, especially that of the Nahuatl. Secondly, Borsò shows, Sor Juana's body of work functioned as a knowledge storehouse because she pulled contemporary knowledge from the most disparate fields, including medicine, into her thinking and work. Thirdly, Borsò talks about a political aspiration, the political commitment to diversity, that was very critically perceived in Sor Juana's clerical environment and that was already Enlightenment-like. Her will to intervene politically marks Sor Juana as the first of a series of politically committed writers from Latin America who can be counted as belonging to a canon of world literature. As the fourth criterion for counting Sor Juana as part of world literature, Borsò looks at an anthropological consideration, noticing the way in which Sor Juana negotiates between literature and life. She is interested here in a reorganization of knowledge, especially with respect to human sensory perception: Sor Juana, according to Borsò, anticipated the European sensualism of the 18th century. And finally, fifthly, Sor Juana shaped new philosophical and theological epistemologies, which for Borsò is one of the most important characteristics of the works of world literature.

Borsò develops her theses on the basis of a variety of texts and genres in Sor Juana's writings, but especially using the text "El divino Narciso” (1685; "Loa to Divine Narcissus"), an auto sacramental (one-act play) that is based on Ovid's text on the theme of Narcissus, which Calderón de la Barca then in turn developed further in his play Eco y Narciso (Echo and Narcissus). What is significant here is Sor 
Juana's multilayer feat of translation and transformation with which she introduces the theological allegories of the genre into New Spain and inscribes a new kind of material, territorial, and physical concretization into the allegorical discourse. Through the translation of symbols and the staging of a diversity of cultures, a transformational space is opened, a hybrid cultural space of the Spanish territory in Latin America, whose influence should not be underestimated. In addition to Sor Juana, the Peruvian Juan de Espinosa Medrano (c. 1629-1688) and the New Spain writer Carlos de Sigüenza y Góngora (1645-1700) should also be mentioned. Through a hybridity that incorporates various modes of perception of reality and various modalities of knowledge, the textual space calls the authority of the colonial order into question.

An understanding of the transformational power of the colonial baroque is crucial to determining the origins of the concept of world literature in Latin America. In his text "La curiosidad barroca" (Baroque curiosity; published in La expresión americana in 1957), José Lezama Lima challenges the depiction of assimilation and advocates a view that is based not on the hegemonic relation but on a free adaptation and an exchange of models. He also points to examples from Latin American clerical artistic practices, to which he ascribes greater artistic freedom and more resistance to the restrictive world of the CounterReformation than was to be found in Spain at the same time (Lezama Lima 1977 [1957]). It is only in the last few decades that there has been any adequate appreciation and categorization of the related artistic achievement, and to a certain degree it is yet to come.

\section{Modernismo}

The emergence of a particular and specifically Latin American literary tradition is usually considered by literary historiographers to have begun only with the representatives of Modernismo - and this is often expressed as the somewhat undifferentiated thesis of a first emphatic literary independence of Latin America from Europe. Using the example of the Uruguayan essayist and writer José Enrique Rodó (1871-1917), however, it can be shown that in fact the cultural heritage of European intellectual history was instead creatively transformed, both formally and in terms of content, and then further processed in a cuttingedge way (Ette 1994: 309).

There are definite parallels to someone like Sor Juana Inés de la Cruz in terms of these processes of artistic adaptation, although the context and the literary media are of course completely different. Rodó was received as a literary figure on the world stage because he achieved the new and so important symbiosis 
of an orientation towards the Western cultural heritage with autonomous elements. This early example makes it clear what was to remain decisive for the categorization of Latin American writers as world literary figures throughout the various phases of their reception: in order to be able to be dealt with as literary figures on the world scene, they had to demonstrate that they were able to connect to classical elements of the European tradition. A similar dynamic can be seen playing an important role for other modernistas as well. In the case of José Martí (1853-1895), for instance, we would have to mention his volume of poetry Versos libros, first published, posthumously and in an incomplete version, in 1913: that volume introduced a completely new, unrhymed poetic language while at the same time processing a number of literary styles, tying in with a baroque rhetoric and, particularly, with romantic themes and models. A new and particular writing style that was received as specifically Latin American can be noted in Rubén Darío’s (1867-1916) famous book of poetry Azul, published in 1888; that style was accessible in Europe because it was heavily influenced by contemporary French literature. In addition to a reception that involved French influences (in particular with Dario) and one that was connected to English-language literature (which could be seen very clearly in the case of Martí), there is another, further, development that can be seen in the example of Rodó or of Modernismo, which is decisive for the reception of modernist writers in the context of world literature.

In the second half of the 19th century, the literary field in Western Europe developed a relative level of autonomy, which had decisive consequences for the establishment of denominative processes in literature. Pierre Bourdieu has famously established that the effects of the Dreyfus Affair went far beyond France and produced important changes: the positive connotations of the concept of the intellectual in Europe, for instance, first emerged with that affair, in which Emile Zola, according to Bourdieu (1992: 186-87), cemented the literarycultural sphere's claims to autonomy with his very clear public, journalistic statement supporting the young Jewish officer who had been unjustly accused. Scholars and writers who had acquired symbolic capital within their own narrowly defined fields now consciously used that capital to comment on topics of general public interest.

In Latin America, there was no question of an economic infrastructure in the literary field at that time. However, in the Modernismo movement, one can perceive a cautious echo of the Western European developments toward autonomy. With José Enrique Rodó, literary practice in Latin America gained a new importance. He addressed questions about the coordinates of a potential indigenous Latin American culture, identity, and literature, as well as their relationship to European and North American intellectual and cultural history. 
In Ariel, Rodó's most widely received work, first published in 1900, the protagonist, Próspero (named after the main character in Shakespeare's The Tempest), following the teachings of the French philosophers Jean-Marie Guyau and Ernest Renan, proclaims an ideal of education that is genuinely universalist - a premodern, precultural, holistic state that was still possible before the "functional differentiation of social subsystems" (funktionalen Ausdifferenzierung gesellschaftlicher Teilsysteme; Lohmeier 2007: 9) that was so typical for modernization. Even in his Americanism, Rodó did not completely disengage himself from European culture.

Martí also pursued the project of intellectual unity for Latin America as a precursor to a political union, along the lines of what Rodó's Próspero proclaims. Its positioning in the context of the flow of journalistic information is very revealing in terms of a slowly developing and also structural independence of the literary field: while Martís early magazine projects demonstrate the still dominant flow of information from East to West, Ottmar Ette has shown, using Martí's writings, how an intra-American flow of information from North to South was also established: "His [Martî's] chronicles and essays perfectly document a transfer of knowledge that was, for the first time, self-directed, and that was oriented to the needs of Latin American countries" (Ette 1994: 308). ${ }^{25}$

But how, after Modernismo, did something resembling a relatively autonomous field develop further in Latin America? Purely sociological factors would speak against any relative autonomy for the literary sphere in Latin America at the end of the 19th century. The illiteracy that was still widespread not only reduced the potential for readership from a purely statistical point of view but also made it more difficult for an intellectual elite to be constituted. The Mexican cultural theorist Carlos Monsiváis has described the difficult reception conditions at the time in Latin America (2000: 115), which included a fragile library system; a very small network of bookstores, which were located primarily in the capital cities; and a small number of publishing houses, which were sometimes unstable. The only example of a successful reception, Monsiváis writes, is Jorge Isaacs's bestseller María, published in 1844.

The oft-repeated thesis that with Latin America's Modernismo, we could already speak of a movement that was developing parallel to Europe not only in terms of content but also in terms of the conditions of the literary marketplace, does not hold water. The autonomy that Bourdieu has identified in France's

25 "Seine Chroniken und Essays dokumentieren in hervorragender Weise einen erstmals selbstgesteuerten Wissenstransfer, der an den Bedürfnissen der lateinamerikanischen Länder orientiert ist.” 
literary sphere in the second half of the 19th century cannot be projected onto Latin America, in spite of initial attempts at developing greater autonomy. Commentaries on society and politics remained limited, probably mostly because the actors were still firmly integrated into the political and economic institutions: until the 1960s, almost all writers, including Rodó, held government positions. As long as literacy and democracy were still limited to a small minority in Latin America, the development of an independent infrastructure of literary production was not yet possible. From the conditions in Latin America, which were not comparable to the structures available in Europe, given that at that point not even the concept of the intellectual could be transferred to Latin America, Nicola Miller draws the conclusion that "in Spanish America, by contrast, adoption of the word was symptomatic of the fact that the conditions for professional intellectual life were only incipient; in other words, the resonance of the idea was dependent on a nascent modernity" (1999: 4). ${ }^{26}$

The following literary generation, the Latin American avant-gardes of the 1920s, also faced severe restrictions with respect to the structuring and autonomy of the literary field. They wrote mostly poetry, which stayed among an exclusive circle of readership and therefore was not able to have a broad-ranging impact. As experimental and progressive as their works may have been, including those of the highly productive writers Vicente Huidobro (1893-1948) and César Vallejo (1892-1938), they were not able to create a full-fledged literary production infrastructure for themselves.

\section{Jorge Luis Borges}

In Latin America's transition to structural change and the freeing of its literary from its political sphere, Jorge Luis Borges (1899-1986) plays a special role. He was the first Latin American writer who could be counted among the canon of world literature, receiving correspondingly international acclaim, even though, in his lifetime, he was more successful among other writers and among publishers and critics than he was a bestselling author. His oeuvre occupies a monolithic position within Latin American literature, and it turns out to be extremely difficult to assign Borges to any particular literary group or movement, any particular genre or turning point. His work is extraordinarily dense with philosophical, religious, and artistic discourses, reflections, and contexts and is characterized by

26 See also Müller (2004: 74-78). Gonzalo Navajas (2019) recently presented a valuable study on the development of the figure of the intellectual in the context of modern ideologies. 
texts that oscillate among literary-critical essays, realistic prose, and fantasy. This universalist approach (Bell-Villada 1999: 295) is also what makes it impossible to count Borges among the members of the Boom generation, given that its most important representatives wanted to create a genuinely Latin American literature with its own inherent operational mechanisms, genres, and contents. He can also hardly be classified as a purely modernist or postmodern writer. The question of why Borges's literary creations were canonized and what qualities raised them to the rank of world literature is a very complex one; Alan Pauls (2004), in particular, has addressed this question in exemplary fashion. Pauls emphasizes the many different forms that the response to Borges's work has taken, as well as the diversity of literary elements that characterize that work. He details the aspects of what makes this author's writing so unmistakable not only through his literary texts but also using interviews, postcards, letters, and radio reports, among other documents. Pauls also looks for clues in Borges's voice, his physicality, and especially on a level that he designates as both intimate and theatrical, private and public: "El Borges on stage" (Pauls 2004: 8). And while Borges certainly occupies a unique position in literary terms, this concept of "Borges on stage" does find an echo in the mise-en-scène of the Boom writers in a literary sphere that was undergoing rapid structural change.

One thing that is very interesting in the context of the question of world literature is the universalist concept, often applied to world literature, that Borges outlines in the essay "The Argentine Writer and Tradition" ("El escritor argentino y la tradición”), published in 1955. In that piece, he addresses contemporary positions on the question of what an Argentine or Latin American literature should look like, and he formulates a poetology that goes beyond national poetic classifications. At first, Borges criticized the fact that the literatura gauchesca, Gaucho literature, which was praised and proclaimed as a national Argentine literature, was actually not a continuation of the actual popular Argentine poetry, poesia popular. The imitation of folksy language and pseudo-mimetic representation of imaginary Argentine stereotypes was, he wrote, exactly the opposite of poesía popular. This actual popular poetry reflected, instead, much larger (epistemological, religious, and philosophical) global concerns, and in doing so used a more universal language and a variety of topically appropriate images and metaphors. Borges cites verses from Enrique Banchs's (1888-1968) La urna, in which Banchs uses the image of the nightingale, with the references it carries from both Greek and Germanic cultural history, in order to create a "higher poetry." Thus, Borges writes, it is a mistake for Argentine poetry to manifest itself exclusively in specifically Argentine characteristics. Borges cannot understand how one could categorize a writer by nationality, as a French or English poet, if his writings always treat themes that also go beyond any such categorizations (Racine with his 
Roman and Greek topics, Shakespeare with Danish ones). He rejects the positions of an Argentine national literature and demonstrates that these are relatively new concepts with no basis in literary history. In this he also distances himself from the nationalistic assumptions, reminiscent of the 19th-century eugenicist, Darwinist, and racist theories of heredity, according to which a certain kind of writing is a result of historical lineage: if Argentines write like Spaniards, according to Borges, this is less a testimony to their inherited ability than it is proof of the universal intellectual versatility of the Argentines.

The opposite thesis, namely that the Argentines, because of their status as a still young and only recently founded nation (1816), have no past, are therefore a tabula rasa in terms of cultural history, and consequently must emancipate and distance themselves from Europe all the more, is equally untenable to Borges, however. For the historical events taking place in Europe in the 20th century - whether the Second World War or the Spanish Civil War - as conflicts between higher political and ideological positions, had just as much of an emotional effect on the Argentines, both as descendants of Europeans and as global citizens. Borges argues for an emancipation from all models that determine art and thought and calls for a self-confident approach to the European past and European cultural history (see Borges 1955).

Finally, it is probably also his repeated demand for Argentine, South American, and Latin American literature to take a universalist orientation that makes Borges into the key reference point for a large number of writers, and not only Latin American ones: writers who reject foreign control and restriction of their intellectual horizons and who often, even if in very different ways, work intertextually; writers such as Umberto Eco from Italy, Roberto Bolaño from Chile, ${ }^{27}$ or Valeria Luiselli from Chile.

\section{The Boom}

Now that we have seen that Jorge Luis Borges was the first global literary figure who offered a poetology showing a path into the future that was relevant to this context and who made a broad international impact, I would like to trace the structural developments that paved the way for a much more sweeping reception of Latin American writers. According to Nestor García Canclini (1989), there were important developments in Latin America between the 1950s and the

27 On Roberto Bolaño's intertextual work and his global reception, see Benjamin Loy's study (2019). 
1970s that indicate structural change: an economic upswing, urban growth, an expansion of markets for cultural goods, growing school and university attendance, and a reduction of illiteracy to 10 or 15\%. In Argentina, Mexico, and Brazil there was a surge in the book industry around 1940. The Peruvian writer Mario Vargas Llosa noted in the mid-1960s that a more favorable climate for literature was finally emerging in Latin America. Book clubs and reading circles began to spread, and the bourgeoisie discovered that books were important and writers were something more than harmless fools; they discovered that writers had a task to fulfill (Vargas Llosa 1971 [1967]: 19). Martha Zapata Galindo uses the example of the newspaper section México en la Cultura, which was a feature of the newspaper Novedades, later replaced by the section La Cultura en México in the newspaper Siempre, to show how, in the 1950s, the most important intellectual groups in Mexico formed in connection with magazines, the cultural sections of newspapers, or university institutions, where they accumulated prestige and cultural power. This was also the point in time when writers and intellectuals began to distance themselves from the official nationalism of the Mexican state. Another important way station on the road to broader access to the globally relevant denominating centers that make decisions about world literature coming out of Latin America lies in the current founding or expansion in Mexico of publishing houses such as Era, FCE, Joaquín Mortiz, and UNAM, which have proven to be very open to younger writers (Zapata Galindo 2003: 103-5; see also Müller 2004: 78-79).

This structural change all across Latin America prepared the ground, in a continent-wide effect, for Latin American writers to be recognized internationally for the first time. The inextricable linkage of membership in the world literary canon with practical sociological factors can be seen in an exemplary fashion in the novelists of the 1960s, many of whom are counted as part of the Boom in Latin American literature. The first socioeconomic indicator for the autonomy that was achieved, even if it was only relative, was the institutional independence from the governmental system of someone like Gabriel García Márquez (and other writers of his generation), which had never before been seen to that degree in Latin America. Even more decisive, however, was the ethical independence that these writers asserted, appealing to the people as opposed to the political class, and for the sake of which they rose to become bearers of universal values. They claimed to articulate the needs of the people, of the pueblo, which they saw as being both economically oppressed by capitalist class interests and culturally controlled by European hegemony. These writers asserted their status as intellectuals by intervening in the political sphere while appealing to the genuine norms of the literary sphere. Their independence from state and social authorities and the associated independence of the literary sphere that 
was implied by that was a decisive prerequisite for gaining access to the publishing centers of Europe and the United States (Müller 2004: 79, 275).

The Latin American literary Boom of the 1960s - involving the novels of Gabriel García Márquez, Mario Vargas Llosa, Carlos Fuentes, Julio Cortázar, and others, which quickly became best sellers - is associated not only with sociological but also with other factors that are highly relevant to the canonization processes of world literature. Julio Cortázar summed up the lowest common denominator of the Boom novels by saying "What is the Boom if not the most extraordinary awakening of the Latin American people to their own identity?" (Qué más es el boom, si no la más extraordinaria toma de conciencia del pueblo latinoamericano de su propia identidad?; quoted in Rama 1982: 244). From an intra-literary standpoint, questions of identity very clearly stand at the heart of the literary production of the Boom generation. The focus is on the process of becoming aware, the search for identity, whether that takes place through recourse to pre-Columbian myths, cyclical structures of time, or experimental narrative methods.

The movements for political and social liberation that were becoming ever more urgent on the subcontinent also played a decisive role. The Cuban Revolution can be seen as the beginning, even though the term "Boom" is certainly a reference to the purely economic successes, which are due mainly to the publisher Seix Barral in Barcelona, that introduced the Latin American writers to the market. All of the Boom writers shared a belief in the Cuban Revolution: they wanted to give a voice to the people, which had been condemned to silence through their illiteracy and poverty, and in this they were very much in line with Sartre's concept of the committed intellectual. At least this was true until 1971, when Herberto Padillo was arrested by the Castro regime because of a critical volume of poetry and, soon afterwards, made a public confession of guilt in a show trial. For many of Latin America's Marxist or Marxist-inspired intellectuals, this shook their belief in the Cuban utopia. They then distanced themselves from the Communist regime with a letter of protest to Castro and a petition in Le Monde.

\section{Successes and Mechanisms of Exclusion in the Boom}

Inherent to both the concept of identity and the concept of Latin America that form the basis of the successes of the Boom are mechanisms of exclusion that need to be critically examined and, in part, still require research. The central questions are those of gender and genre: namely why there is not a single woman even in the wider circle of the writers considered part of the Boom, and 
why the Boom only affected narrative prose. Nor is there, in principle, any justification for the fact that Brazilian literature played such a marginal role in this massive global circulation of Latin American literatures. ${ }^{28}$ Not only that, but how can we evaluate the fact that all of the members of the Boom were not only male and Spanish-speaking, but also belonged to the subcontinent's white middle and upper classes? What reasons are there for the fact that such extraordinary writers as Juan Carlos Onetti, Guillermo Cabrera Infante, Antonio Di Benedetto, and Salvador Elizondo, all of them contemporaries of the Boom writers, did not take part in the global success that was accorded to the network around García Márquez, Fuentes, and Vargas Llosa? The analysis of these implicitly operating exclusion mechanisms touches on the fundamental issue of translation as a sine qua non for world literature (see Venuti 2012). If, as David Damrosch famously puts it, a main criterion for world literature is "writing that gains in translation" (2003: 288), then we have to ask the question of what role the complex field of translation plays, in reference to these exclusionary processes, within the global circulation processes of literature. Emily Apter has pointed out that the texts that then become especially problematic are those for which elements of untranslatability would seem to make them less compatible with publishers' marketing and publication strategies (Apter 2013). However, the interest in theoretical questions of untranslatability has, for a while, obscured the concrete politics of translation, for instance with respect to funding for translation or the role that individual translators play. ${ }^{29}$

\section{After the Boom}

In the later work of the Latin American writers who had become stars, we can see a departure from the great projects of identity creation starting in the 1970s, but at the very latest from 1989 on. This shift comes down to a change in focus from the pueblo to the público, in other words a shift from the (Latin American) people, for whom these writers were supposedly speaking, to the public, most saliently a European and North American public, towards whose tastes and

28 On various aspects of the marginalization of Brazilian writers and of women, see Leonie Meyer-Krentler's work on Clarice Lispector: Clarice Lispectors doppelte Isolation (Clarice Lispector's double isolation, in production), on the dynamics of translation and reception in the context of current debates over world literature, as well as her volume Clarice Lispector (2019) in the series "Leben in Bildern" (Lives in Images), published by Deutscher Kunstverlag.

29 Roig-Sanz and Meylaert's edited volume on Literary Translation and Cultural Mediators in "Peripheral" Cultures. Customs Officers or Smugglers? (2018) is an exception. 
expectations the writers increasingly turned. There is a retreat into an emphasis on readability, and narratives that look to European and North American examples not only in their narrative strategies but also in their choice of subjects and finally, the literary staging of the writers' own early work, most saliently in the form of distancing but at the same time also constantly playing with (and evoking) their own successes.

Starting in the 1990s, younger writers rejected the topics of the 1960s, even more decidedly than had their literary predecessors. Thus, for example, in their manifestos, the Crack group, which included Jorge Volpi, and McOndo, including Alberto Fuguet, parodied Latin American specificity and often ostentatiously turned away from Latin American themes in their work. It is unclear whether that is related to a decline in the fortunes of the Spanish and Latin American publishing industry (see also Müller 2004: 257-61).

After the Boom, with its large sales successes in Europe and the United States, there is primarily one 20th-century Latin American writer whose work was considered to be among the ranks of world literature by literary critics, international publishers, and the field of literary studies: Roberto Bolaño (1953-2003), from Chile, whose influence and impact were as monolithic in his time as Borges's were in his own. Bolaño spent his youth in Mexico, then lived in Spain from 1977 onwards. After his death in 2003, and especially after the great success in the United States of his posthumous novel 2666, the reception of his work among writers and critics was unparalleled, although he was not all that successful in the marketplace at first. Bolaño's poetology, like Borges's, is not so much Latin American. His understanding of literature is more universalist, pursuing literary references and influences from the most varied times and traditions, referring equally to Borges's stories and to Baudelaire or Mallarmé. His themes are very deeply anchored in the political and social Latin American present, however, especially as regards experiences of exile and violence. One of the outstanding achievements of Roberto Bolaño's literary work is that it awakens an understanding that these topics are not solely Latin American themes, even though they are told in their Latin American contexts, for instance that of the countless murders of women in the Mexican/U.S. border region in the 1990s $(2666,2004)$. 


\section{II.2 Patterns of Integration into World Literature}

With the following reflections I introduce three variant forms of reception that show how particular authors or works can assert themselves within world literature through the ability of the literary works to connect to established discourses and traditions as well as through the programmatic (self-) positioning of the authors. My first example is Elena Poniatowska, whose work is characterized by a particular ability to connect to the leftist political discourses of the 1970s and 1980s, while at the same time the question of exclusionary phenomena also plays a role. ${ }^{30}$ Secondly, I look at Jorge Volpi, who achieved worldwide success through his programmatic departure from the expectation of specifically Latin American writing and whose texts demonstrate a high degree of compatibility with the classics of Western history and history of science. Thirdly, Juan Gabriel Vásquez serves as an example of a specific kind of connection with traditions established in Europe and of the tendency to disengage, as a writer, from specifically Latin American identities and to position one's own work explicitly as world literature.

\section{Elena Poniatowska}

The work of the Mexican writer Elena Poniatowska (b. Paris 1932) has had a relatively small circulation in the context of the Boom. It has been pointed out over and over how exclusively male, white, and upper middle class the successful Boom writers were. Pierre Bourdieu, writing about social practices that promote male dominance, says: "whatever their position in the social space, women have in common the fact that they are separated from men by a negative symbolic coefficient which . . . negatively affects everything that they are and do, and which is the source of a systematic set of homologous differences" (2002: 93; quelle que soit leur position dans l'espace social, les femmes ont en commun d'être séparées des hommes par un coefficient symbolique négatif qui . . . affecte négativement tout ce qu'elles sont et ce qu'elles font, et qui est en principe d'un ensemble systématique de différences homologues; 1998: 100; emphasis in the original; see also Sánchez Prado 2018c: 140-41). This certainly also applies to the Latin American literary field of the 1970s and 1980s, a phase that was decisive for the reception of Poniatowska. At the same time, we must note that against this background,

30 On exclusionary processes and female Mexican writers, see the chapter on "The Idea of the Mexican Woman Writer” in Sánchez Prado (2018c: 139-82). 
Poniatowska was often made into the exemplar of a woman writer who was also compatible with the positions of leftist European political discourses. Poniatowska contributed to the canon of the testimonial novel, the novela testimonial, with her decidedly politically motivated writing. Her work ranges from critical journalism to a very specific kind of literary writing that mixes interviews, data, and factual reports with fictional components. The point is often to give a voice to marginalized social groups. The distribution of her work was very much boosted by the interest of (overwhelmingly female) literary scholars in the United States in the 1970s and 1980s (Schuessler 2007: 243). Especially her two books Hasta no verte, Jesús mío (1969; Until We Meet Again, 1988; later Here’s to You, Jesusa!, 2001) and La noche de Tlatelolco (1971; Massacre in Mexico, 1975) were given an intense and extremely positive reception.

La noche de Tlatelolco, a chronicle, based on interviews, of the bloody events of October 2, 1968, was first published in English in 1975 by Viking Press in New York (as Massacre in Mexico, translation by Helen R. Lane) and is considered one of the classics of Latin American testimonial literature. Cynthia Steele, in her 1992 study Politics, Gender, and the Mexican Novel, 1968-1988: Beyond the Pyramid, for example, describes Poniatowska as being "responsible," along with Carlos Monsiváis, "for converting the testimonial novel and the social and political chronicle into the quintessential narrative genre of the seventies and eighties" (11, cited in Schuessler 2007: 247). Steele then goes on to emphasize Poniatowska's commitment to the

powerless, marginalized, and oppositional members of society who lack access to selfrepresentation in print and the media: the handicapped, AIDS victims, earthquake victims, women artists and writers of the past, political performers, political prisoners, trade-union organizers, opposition leaders, servants, garment workers, Indian women.

(11-12, cited in Schuessler 2007: 247)

Here we can see one of the two important strands in the international academic reception of Poniatowska, which focuses on the leftist social criticism towards which her writing tends and the literary documentation of marginalized living conditions, a strand that is also prominently represented in more recent publications:

Elena Poniatowska's chronicles are effective, literary antidotes to the actions of the political system. To official and temporal oblivion, [she offers] memory and historical traces; to falsehood and the misrepresentation of facts, authenticity, and faithfulness; to superficiality, what is necessary and authentic; to the bare recording of facts, a creative and poetic treatment. ${ }^{31}$

(Poot Herrera 2017: 21)

31 "Las crónicas de Elena Poniatowska son antídotos literarios y efectivos a las acciones del sistema político. Frente al olvido oficial y temporal, la memoria y la huella histórica; frente a la 
Over the years, in addition, a number of academic works have appeared that analyze Poniatowska's writing through the lens of the paradigm of "women's writing," often in the context of other Mexican (or Latin American) women writers such as Elena Garro or Rosario Castellanos. Generally speaking, it can be said that her work is highly valued among literary scholars and critics; Poniatowska is often mentioned in the same breath as Octavio Paz, Carlos Fuentes, and Gabriel García Márquez. Since the beginning of the 1970s, both her journalism and her literary writings have been the subject of a constantly growing number of academic publications: by 2007, 24 dissertations had been written on her work in the United States alone. As a comparison, in the same time period, 70 dissertations were written on Carlos Fuentes, 53 on Octavio Paz, and 33 on Rosario Castellanos. Poniatowska was also a visiting professor at various universities in the United States and received a mind-boggling number of honorary doctorates (Schuessler 2007: 254). Poniatowska's literary fame was further solidified and publicized by a series of literary awards, ${ }^{32}$ culminating in the bestowal of the Cervantes Prize in 2013, the most prestigious award for Spanish-language literature and an honor that had only been bestowed on three women before her (see Benmiloud and Lara-Alengrin 2014: 18). And in 2008, an Elena Poniatowska Literary Prize for Spanish-Language Literature was even established, which is now awarded every year at the Mexico City Book Fair.

The fact that Poniatowska's appeal spread far beyond the borders of Mexico, the United States, and the Spanish-speaking world is evidenced by the fact that in 2002, she won the Chinese prize for the best foreign novel for La piel del cielo. ${ }^{33}$

falsedad y tergiversación de los hechos, la autenticidad y la fidelidad; frente a la superficialidad, lo necesario y auténtico; frente al escueto registro de hechos, el tratamiento creativo y poético.” 32 Among other things, Poniatowska was the first woman to receive the Mexican National Journalism Prize in 1978, in 2002 she received the National Prize of Sciences and Arts, and in 2004 Columbia University's venerable Maria Moors Cabot Prize for journalism. When she won the Alfaguara Prize (in 2001, for La piel del cielo [The Skin of the Sky]), it increased her visibility in the entire Spanish-speaking world (Schuessler 2007: 243). She has also received prestigious international literary prizes, such as the Rómulo Gallegos International Novel Prize (in 2007 for El tren pasa primero [The Train Passes First]), the Premio Biblioteca Breve prize (in 2011 for Leonora), and of course, as noted above, the Cervantes Prize (in 2013). In 2006, Poniatowska was the first Mexican woman to receive the International Women's Media Foundation's lifetime achievement award, in recognition of her stature as a model for countless young journalists and the services she rendered through her weekly literary workshop, where some of Mexico's most promising female literary talents have received their training (see Geddis 2007; Schuessler 2007: 256). She declined the Villaurrutia Prize, which she was awarded for La noche de Tlatelolco, because, she said, she asked herself, "who will give an award to the dead?" (¿quién iba a premiar los muertos?; Benmiloud and Lara-Alengrin 2014: 17).

33 See http://www.china.org.cn/english/culture/51680.htm. 
Poniatowska is one of the best-known Mexican writers in China, as shown by the following quote about Guillermo Pulido Gonzalez, the director of the Institute for Mexican Studies at the Beijing Foreign Studies University: "When Guillermo Pulido Gonzalez first worked in China from 2008 to 2010, he was amazed that the Chinese people he encountered had been exposed to such Mexican writers as Carlos Fuentes, Elena Poniatowska and Octavio Paz through Chinese translations” (Zhou 2015). And yet we should not be all that surprised by this, because leftist literature in the testimonial vein benefited from a very grateful, intensive reception in China at that time. ${ }^{34}$

If we take a closer look at the international circulation of Poniatowska's books, we can see that over the course of decades, they have been consistently translated into many different languages: in addition to English, they have been translated into Polish, French, Danish, Dutch, German, Russian, Japanese, Italian (see Schuessler 2007: 258), and, as we saw, also Chinese. What is striking is that in the different countries very different titles were chosen to be translated. The novel Dos veces única (Twice only), for example, which was published in 2016 by Seix Barral, was also published in Poland that very same year, but not translated into any other language. The only Chinese translation, on the other hand, is of a title that was otherwise only translated into English (and that only a year after the Chinese edition appeared): La piel del cielo (The Skin of the Sky), which won the Alfaguara Prize in 2001. There was apparently no pattern of reception in publishing for her books that could have then developed a stronger assertive force for the work, helping Poniatowska to a broader reception as well as to success in terms of sales figures.

When she was asked, in an interview, about why, for instance, her book Hasta no verte, Jesús mío, which appeared only two years after Gabriel García Márquez's Cien años de soledad, did not receive anywhere near the same kind of international response, Poniatowska cited the fact that, first, as a woman writer she had a much more difficult position in the literary field than her male colleagues did, and second, as testimonial literature, the form of the book bordered on journalism (Pino-Ojeda 1998: 145). Questions of literary genre certainly play a role here; the mixture of reportage-like and literary elements and Poniatowska's collage-inspired style apparently didn't really fit into the marketing categories of the international publishing houses. So, for instance, one unresolved question is why La noche de Tlatelolco (1971), which

34 See Yehua Chen's dissertation (in press) on the translation and circulation of Latin American literatures in China, in which, among other things, she examines the political dimensions of the reception of these literatures in the 20th and 21st centuries during various phases of the development of the Chinese publishing field. 
has been consistently counted as one of the writer's central works and was one of the bases for her fame, was for a long time apparently not translated into any language but English (1975, as Massacre in Mexico). This gap is particularly striking in the German literary market, and I will go more deeply into the background of the publishing politics involved in that gap in section III.2.8.

When we look at more recent trends in international reception, we can see some tentative new developments in recent years. For instance, Poniatowska's first novel, Lilus Kikus, which was first published in 1954 in Mexico, only began circulating internationally a half century after its appearance: it was translated into French and English in 2005 and into Italian in 2009. Poniatowska's United States publisher attributes the slowness of the novel's reception to three factors. First, when the novel was published in 1954, it was labeled as a children's book. Then, the author was an unknown woman. And finally, the feminist features of the novel did not resonate with the readership when it was first published, whereas in the 21st century that was precisely what people valued. ${ }^{35}$ In Poland at the moment, publishers are very involved with Poniatowska's writings, which has to do both with the Cervantes Prize that she received in 2013 and with the writer's Polish ancestry. Two of the three Polish translations of Poniatowska's work were published in 2016 and 2017, respectively. In April of 2017, Marcin Żurek dedicated an extensive article to Poniatowska's life and work, in which he also announced that he was in the process of working on a translation of her Juan Soriano, niño de mil años (Juan Soriano, thousand-year -old child; Żurek 2017). And the very important La noche de Tlatelolco has also been available in French since 2014, thanks to the small Toulouse publishing collective CMDE, under the title La Nuit de Tlatelolco. Histoire orale d'un massacre d'État (The night of Tlatelolco. Oral history of a state massacre). From all of this we can draw the conclusion that Poniatowska's work is now slowly gaining a broader international reception.

\section{Jorge Volpi}

Jorge Volpi (b. 1968 in Mexico City) is, famously, the head of the literary Crack Movement, which established itself in the mid-1990s with its own manifesto. The main concern of groups like Crack or also McOndo is a rejection of the discourse of magical realism. In other words, by that point, the expectation of a

35 See the website of the University of New Mexico Press: https://unmpress.com/books/liluskikus-and-other-stories-elena-poniatowska/9780826335821. 
specifically Latin American kind of writing from writers who are originally from Latin America had, at least among scholars of Latin American literature, finally become obsolete. This paradigmatic positioning, which was partially reflected in manifestos in the second half of the 1990s, then quickly became established as canonical within Latin American literary histories. It is therefore relevant, in asking how world literature is made in the first place, to determine what new patterns might facilitate the world literary reception this paradigm shift produces. What are the breaks and fault lines along which this realignment runs in Latin America itself, and what receptive filters are encouraged internationally as a result?

Jorge Volpi had his international breakthrough with the novel En busca de Klingsor (In Search of Klingsor), which was published in 1999 and deals with the Nazi regime's nuclear bomb project. Volpi had published five novels in Mexico before that: A pesar del oscuro silencio (1993; In Spite of the Dark Silence), about the Mexican poet Jorge Cuesta; Días de ira (1994; Days of fury); the political novel La paz de los sepulcros (1995; The Peace of Tombs); El temperamento melancólico (1996; The melancholy temperament); and Sanar tu piel amarga (1997; Healing your bitter skin). En busca de Klingsor, however, was the first one that appeared outside of Mexico; it was published in Spain by Seix Barral and changed Volpi's career as a writer, as happened with so many other Latin American writers. The novel was translated into 34 languages and sold in more than forty countries. ${ }^{36}$

Carlos Fuentes described En busca de Klingsor as a "moral fable of our time” (cited in Regalado López 2013: 101), and Guillermo Cabrera Infante spoke of a "German novel written in Spanish" (novela alemana escrita en español; quoted in López de Abiada and Leuenberger 2004: 359), which is probably based not only on the historical references to Germany but also on the implicit connections to Thomas Mann's Doktor Faustus. The genre is hard to define, but Cabrera Infante uses the term "science fusion" (ciencia-fusión, quoted in López de Abiada and Leuenberger 2004: 359), because the book combines science with history, politics, and literature. This mixing of genres, which goes far

36 En busca de Klingsor first circulated in Europe and the United States before the novel was then also received in the Latin American market (López de Abiada and Leuenberger 2004: 358). In 1999, the year that it was published in Spain, the translation rights had already been sold to publishers in the United States (Scribners), Great Britain (Fourth State), Germany (Klett-Cotta), France (Plon), Italy (Mondadori), and in the Netherlands, Brazil, Portugal, and Israel - rights worth a total of half a million US dollars (Ángel Villena 1999). Only a year and a half after its first publication it was already in its fifth printing in Spain and its seventh in Mexico (Hunziker 2005: 59). In 2004, Volpi himself wrote that the Spanish-language edition had already sold 70,000 copies (August 5, 2004 email, quoted in Hunziker 2005: 59). 
beyond the classic outlines of a novel, comes up as a topic over and over: Volpi's work is described as "a sort of reasoned compendium" or "a kind of popular encyclopedia of modern science" (una suerte de compendio razonado; una especie de divulgativa enciclopedia de la ciencia moderna; Solano 1999: 13, quoted in Hunziker 2005: 57). The novel is said to be

one of the most complex and captivating novels written in Spanish in recent times: an intensively documented narrative that is, in turn, fiction and testimonial, thriller or spy novel, a historical and scientific chronicle, a tableau of fascinating and contradictory characters, a history of fatal loves and obsessions, and finally, a novel of ideas. ${ }^{37}$

(Dés 1999: 28, quoted in Hunziker 2005: 58)

In an interview with Volpi in 2000, Mihály Dés, the editor of Lateral, classifies the worldwide success of En busca des Klingsor this way: "the reception of the novel and the multiple foreign contracts are signs of a recognition that has not been seen since the novels of the Boom" (la recepción de la novela y las múltiples contrataciones extranjeras son muestras de un reconocimiento que no se ha visto desde las novelas del boom; Dés 2000: 28-29, quoted in Hunziker 2005: 59).

As already mentioned, neither the characters nor the scenarios in En busca de Klingsor are Latin American - in accordance with the Crack credo - which sparked a debate between the advocates of localism, on the one hand, and of cosmopolitanism, on the other. Some voices loudly proclaimed the novel to be a betrayal of Mexican tradition, for instance the literary critic and scholar José Felipe Coria, who was quoted in an article in El País on April 19, 2000 as saying:

We no longer feel that he is a Mexican novelist speaking to the Mexican public; many of his themes are like a nostalgia for Europeanness. The way that he conceived the novel is not like a personal experience but like a choice without a past. He cares more about literary technique than about making an impact or trying to find a personal voice. The most serious issue is how impersonal one can end up being in one's writing. His work could have been created in Europe, South America, or anywhere. ${ }^{38}$

(Ortega Ávila 2000)

37 "una de las novelas más complejas y arrebatadoras de los últimos tiempos escritas en castellano: un relato documentadísimo que es, a su vez, ficción y testimonio, novela de suspense o espionaje, crónica histórica y científica, retablo de fascinantes y contradictorios personajes, historia de amores y obsesiones fatales y, finalmente, una novela de ideas.”

38 "Ya no notamos que sea un novelista mexicano que le está hablando al público mexicano, muchos de los temas son como una nostalgia del ser europeo. Su forma de concebir la novela no es como una experiencia personal, sino como una opción sin pasado. Les importa más la técnica literaria que llegar a impactar o tratar de encontrar una voz personal. Lo grave es la impersonalidad con que se puede llegar a escribir. Su obra pudo haber sido creada en Europa, Suramérica o cualquier parte.” 
The reproach here has to do with the cosmopolitan orientation of a Mexican writer. It applies to the Crack writers in general, but in particular to the novel with which Volpi managed to break through internationally:

the crack novels are a heteroclite combination of unequal stories (some of them are disastrous) whose starting flag is a false cosmopolitanism, a literature written by Latin Americans who had decided to abandon, as if it was too radical, the old national subjects and introduce themselves as contemporary.

(Domínguez Michael 2004: 48, quoted in Alvarado Ruiz 2017: 41)

Other readings of Volpi, however, see him as being more in the tradition of Jorge Luis Borges's short stories such as "Deutsches Requiem" or novels like José Emilio Pacheco's Morirás lejos (You Will Die in a Distant Land) and Roberto Bolaño's La Literatura Nazi en América (Nazi Literature in the Americas). ${ }^{39}$ In addition, Volpi understands literature as a starting point for criticism and rejects absolute dogmas, and his constructive dialogue with critics and literary scholars from Spain, Latin America, and the United States turns out to be productive for his works as well, which constantly question stereotypical assumptions about what it is to be a Latin American writer (see for example Regalado López 2013: 101-4).

In the Latin American context, we can very clearly observe diverging ways of reading, some of which criticize the new literary direction of Volpi's worldwide success in particular and of Crack literature in general as a false cosmopolitanism, and some of which celebrate them as topical transterritorialism, and which, in their contradictoriness, follow the fractures and frictions that always accompany a paradigm shift. The reception of this "new" Latin American literature by literary critics outside of Latin America essentially moves between the two poles of approving a narratively innovative fusion of scientific and literary discourses, on the one hand, and critiquing Volpi's prose as too constructed and too didactic, on the other - which is, finally, nothing other than the critique of the narrative implementation of the merging of different genres and discourses.

His writing was, however, remarkably successful with the reading public, and especially in Germany, where the fact that it was particularly accessible played a role, the subject matter as well as the references to traditional literary elements such as the myth of Parsifal or the Faust story making it easy for German readers to connect to it. In the Welt am Sonntag's special supplement for the Frankfurt Book Fair on October 7, 2001, Volpi's novel appeared in second place on the bestseller list (López de Abiada and Leuenberger 2004: 365).

39 On the marketability of and even booming business in various novels from Latin America dealing with Nazism, see in particular the first chapter in Hoyos (2015: 33-64). 
With En busca de Klingsor, Volpi presented a novel that apparently played a decisive role in shaping a specific pattern of world literary reception. It still remains to be seen to what degree this will prevail as a lasting paradigm in world literature. With his following novels, ${ }^{40}$ Volpi himself was not able to build on the success of Klingsor. But the criteria that had been established - that Latin American writers could take on themes that were considered "Western," using innovative narrative methods; that scientific discourses could be integrated into a novel on a variety of levels; and above all the aspect of the mixing of genres can be identified in a whole series of Latin American novels that have had worldwide circulation in recent years.

\section{Juan Gabriel Vásquez}

In order to get a clearer view of how the conditions of the emergence of Latin American literatures intertwine with questions of becoming world literature in the current phase of accelerated globalization, we will now use a third example, that of Juan Gabriel Vásquez, to demonstrate a further dimension of relatability to established literary traditions. ${ }^{41}$ And one of the central questions here is in what way the concepts of world literature can explicitly influence the actual creation, writers' work itself, today.

In the mid-1990s, the Colombian writer Juan Gabriel Vásquez went to Europe for several years: first to Paris, then to the secluded Belgian region of the Ardennes, and later to Barcelona; now he again lives in Bogotá (Vervaeke 2013: 279). This period of his life, dedicated to the nomadic life in the broadest sense of the term, was formative for Vásquez's artistic development and had, as we know from several different interviews and texts, a very particular influence on

40 In Paris, Volpi wrote El fin de la locura (The End of Madness; 2003), a novel about the relationship between intellectuals and power at the time of the student protests in Paris in May 1968. No será la Tierra (Season of Ash; 2006), a novel about the collapse of the Soviet system in 1989, taken together with En busca de Klingsor and El fin de la locura, makes up Volpi's 20th-century trilogy, which deals with three major historical events: the Second World War, the 1968 movement in Paris, and the collapse of the Soviet system (Regalado López 2013: 97-103). Eight more novels have been released, from a variety of publishers, since 2006, the last of which, Una novela criminal (A criminal novel), was awarded the Alfaguara Prize in 2018 (AFP 2018).

41 The following reflections on Juan Gabriel Vásquez are based on my article "Juan Gabriel Vásquez: ¿representante de una nueva literatura mundial?” (Juan Gabriel Vásquez: representative of a new world literature?; Müller 2017c). 
his work, which has enjoyed an international reception since Los informantes (2004) was translated into English (as The Informers) and French in 2008.

Thus, it is not a coincidence that during his years in Europe, Vásquez headed for two of the world centers of literary creativity and the literary marketplace: Paris and Barcelona, which have to a certain degree defended their positions as literary capitals for Latin American writers over the last two centuries. To Vásquez, Paris remains the "navel of the literary world" (ombligo del mundo literario, De Maeseneer and Vervaeke 2010), as he put it in an interview. At the same time, however, and Vásquez also emphasizes this point, it is a place where a variety of works of the world literary canon, and not only French-speaking ones, came into being.

Juan Gabriel Vásquez, then, left home and went to Paris not (only) to follow the greats of world literature and trace their paths, but also to see to what extent a change of place - in his case a voluntary one - would influence and change his writing, his world view, his literary technique, his subjects and themes, his readings, and, finally, his understanding of his Colombian and Latin American home. ${ }^{42}$ For Vásquez, the geographical shift functions as an experimental form of paradigm shift, which is virulently powerful, in its world-literary reach, on three levels: on the level of poetology, it is evident in ways of thinking about a universal "literature without a fixed abode" (Ette 2016); on the level of the text, it can be seen in the countless intertextual references, both implicit and explicit, that point towards it; and on the aesthetic level, finally, a connection to Gabriel García Márquez - as a Colombian and as a Latin American - is revealed in the terms of world literature. We have interesting statements on García Márquez's aesthetic by Vásquez himself, which he formulated in the short essay "Malentendidos alrededor de García Márquez” ("Misunderstandings Surrounding Gabriel García Márquez”; 2005), thus inserting himself into the reflection on world literature.

In a 2010 interview with Rita De Maeseneer and Jasper Vervaeke, Juan Gabriel Vásquez stated that writing great literature abroad as an expatriate is probably part of the identity of the Latin American writer and intellectual and is in no way something genuinely new in contemporary literature:

Of course it is not something that either I or my generation invented, nor the writers of the Boom, who were all expatriate novelists: Cortázar, Garcîa Márquez, Vargas Llosa, and Fuentes all wrote their great novels far from their own countries. It seems to be at the root of a certain metaphysics of the Latin American writer. ${ }^{43} \quad$ (De Maeseneer/Vervaeke 2010)

42 I am grateful to Sylvester Bubel for important research on Juan Gabriel Vásquez.

43 "Desde luego es algo que no hemos inventado ni yo ni mi generación, ni tampoco los del boom, que eran todos novelistas expatriados: Cortázar, García Márquez, Vargas Llosa y Fuentes escribieron sus grandes novelas fuera de sus países. Parece estar en la raíz de una cierta metafísica del escritor latinoamericano." 
When Vásquez speaks of a metaphysics of writing away from the "motherland," and is even able to recognize in that a unifying pattern among Latin America's unquestionable world literary figures Cortázar, Garcîa Márquez, Vargas Llosa, and Fuentes, he is advocating a thesis according to which literature that can have a chance of being accepted into the canon of world literature can only be achieved through distancing, through an act of self-liberation from habit, from the known and familiar. That includes leaving behind inherited, learned, cherished, but also limiting patterns of thought and attitudes: "establishing a distance from the place you come from, from home" (establecer una distancia con el lugar de donde viene, con el hogar) - this, then, was the impetus for his own emigration. Paris, the "host city for various literatures" (lugar de acogida de varias literaturas), he says, answered technical and thus also poetological questions for him, not least through the tradition and also the density of the literary enterprise there, and thereby became part of his own "personal mythology" (mitología personal), which he shares with so many international and Latin American writers. "My idea was that when I was away from my own country, my writing would manifest itself with less resistance and more elements of wisdom, and taking advantage of greater cross-contamination" ( $\mathrm{Mi}$ idea era que estando fuera de mi país la escritura se haría realidad con menos resistencias y mayores elementos de juicio, y aprovechando una mayor contaminación; De Maeseneer and Vervaeke 2010), Vásquez goes on to say in the interview, and he would under no circumstances like to see his life away from home characterized as a kind of diaspora, because in that formulation there always resonates a "certain pretension of moral superiority" (cierta pretensión de superioridad moral). Even the concept of exile seems inappropriate to Vásquez, as it carries, he says, the connotation of a "curious prestige" (prestigio curioso) as well as a "political coloring” (color político) that always resonates with it because of the political and war-related events of the 20th century (Vásquez 2009b: 179).

For himself, someone who could have returned to his country of origin anytime he wanted without any problems or restrictions, Vásquez chose the term "inquiline" (inquilino), ${ }^{44}$ using an analogy with the animal world to describe his situation: "an inquiline is 'an animal that lives habitually in the nest or abode of some other species", 45 (inquilino es cualquier animal que vive en la madriguera o el nido de un animal de otra especie, 179). He especially likes the feeling

44 Vásquez arrives at this concept of the "inquiline" through his preoccupation with V. S. Naipaul, who was called that by a critic (see Vásquez 2009b: 179).

45 “Inquiline.” Merriam-Webster's Unabridged Dictionary, Merriam-Webster, https://un abridged.merriam-webster.com/unabridged/inquiline. Accessed March 15, 2021. 
of traveling as an inquiline, of being in transit (estar de paso), and he considers this way of life, or more specifically the impulse to move to a foreign country voluntarily, to have a parallel with the act of reading:

Since 1996 I have left three different countries, and it seems more and more likely to me that the reasons one has for living in foreign places end up being similar to the reasons one has for reading good fiction: expanding our unbearably limited, narrow, myopic, provincial notion of human experience, of what is and is not human experience. The only other reason for reading good fiction is to expand our understanding of what good fiction is. And that can be done - at least in theory - without going to live among animals of another species. ${ }^{46}$

This attitude of Vásquez's, however, means that he has to deal with a common prejudice among literary intellectuals (personified and formulated by Philip Roth), namely the question of how an "uprooted" writer can find his or her own subject matter if they don't live in their own country, and Vásquez wants to counter this "Faulknerian tradition that considers that the only way to be universal is to be rabidly local" (tradición faulkneriana que considera que la única manera de ser universal es ser rabiosamente local) and to ask the question: "What does it mean, for a novelist and for his work, to be abroad while that work is being constructed, what does this uprooting mean?" (Qué implica, para un novelista y para su obra, estar en el extranjero mientras esa obra se construye, qué implica el desarraigo?; 180). One answer to this question, for Vásquez, is the hybridization that this kind of literary creative work undergoes: "Writing abroad, just like reading in other languages, means voluntarily submitting yourself to hybridization, to impurity" (Escribir fuera, igual que leer en otras lenguas, es someterse voluntariamente a la hibridación, a la impureza; 184). And in his opinion, it is precisely the Boom writers who succeeded in destroying the Spanish language to a certain extent, redesigning it, and putting aside typecast subjects, which is an important legacy:

This, among other things, is the legacy that the novelists of the Latin American Boom have bequeathed to us: the right to break the Spanish language, to repudiate traditional rhetoric, and to embrace barbarisms. Rayuela, Terra Nostra, Tres tristes tigres: these are

46 "Desde 1996 me he ido de tres países distintos, y cada vez me parece más probable que las razones que uno tiene para vivir en lugares ajenos se acaben pareciendo a las que tiene para leer ficción de la buena: ampliar nuestra noción, insoportablemente confinada y estrecha y miope y provinciana, de la experiencia humana, de lo que es y no es la experiencia humana. Sólo hay otro motivo para leer buena ficción, y es ampliar nuestra noción de lo que es la buena ficción. Y eso se puede hacer - por lo menos en teoría - sin ir a meterse entre animales de otra especie." 
places where the Spanish language of someone like Ciro Alegría, in Latin America, or Azorín, in Spain, is barely able to serve as evidence. ${ }^{47}$

(Vásquez 2009b: 184)

In other words, what the Boom helped to create is a new language, a language "of an itinerant, uprooted, multilingual, and contaminated character" (del carácter itinerante, desarraigado, multilingüe y contaminado), which the inquiline writer also has to use if he doesn't want to sound like an "accountant" (notario; 184, 186).

And so what does the escritor inquilino's choice of topics look like? According to Vásquez, he wants to explore the unknown, he wants - and here, as with the term inquilino, Vásquez refers again to Naipaul - to "revive the reader's awe in the face of a world that is, in its own right, awesome" (revivir el asombro del lector ante un mundo que es, por derecho propio, asombroso; 186), and one of the most important virtues in this exploration of the submersion and reactivation of awe is topically freighted searching (el buscar). The parallel with Jorge Volpi, whose novel En busca de Klingsor includes the search right in the title although in different terms - is inescapable here, and would certainly be worth a closer examination. Vásquez himself is vehemently opposed to the research and criticism that has repeatedly made this kind of "inquisitional investigation" (see "the novel's exploring or intensively questioning condition," la condición exploradora o inquisidora de la novela, 187) of a geographical space or a particular period unavailable to novelists writing in Colombia following Gabriel García Márquez's monumental work. The search for and discovery of stories and subjects in a given space is never "used up" or finished, he writes.

But it was his own personal life path, his travel through Europe as well as his broad reading and his preoccupation with world literary figures such as Joseph Conrad and V. S. Naipaul, that finally led Vásquez to write about Colombia, his country of origin, in Los informantes (2004; The Informers); it was precisely because the country represented the "condition of a dark zone" (condición de zona oscura; 2009: 187) that it became an important subject, if not the central subject, of his novels: "today, on the other hand, it is the lack of certainty that seems to me to be the best reason for undertaking the complex questioning apparatus that is a novel" (hoy, en cambio, la falta de certezas me parece la mejor razón para emprender el complejo aparato preguntón que es una novela; 188). The allusions to world literary subjects in Los informantes, in particular, fit seamlessly into the

47 "Esto, entre otras cosas, nos dejaron como legado los novelistas del boom latinoamericano: el derecho a romper la lengua española, a repudiar las prosas castizas y a abrazar los barbarismos. Rayuela, Terra Nostra, Tres tristes tigres son lugares donde la lengua española de un Ciro Alegría, en Latinoamérica, o de un Azorín en España, sirve apenas dar constancia.” 
conception of this kind of novel of Colombia. Los informantes tells the story of the protagonist Gabriel Santoro, Sr., a professor of rhetoric in Bogotá, who committed a crime during his adolescence: during the Second World War, he falsely and maliciously denounced Konrad Deresser, of German descent and the father of Gabriel's best friend Enrique, causing Konrad to be placed the United States' so-called “blacklist," become interned, have both his professional and his private life destroyed, and then as a result finally to kill himself using a “cocktail of brandy and gunpowder” (coctel de aguardiente y pólvora; 119). After his father's death, Enrique disappears. Seeking revenge, he then has his former friend Gabriel Santoro ambushed: in a machete attack by strangers, Gabriel loses several fingers. For decades, Gabriel attempts to keep his crime a secret, among other reasons also so as not to destroy his successful career, but his son, who shares his name, finally discovers it and, after his father dies in an accident in the early 1990s, writes a book called Los informantes.

Vásquez begins the novel with two prominently placed quotations from Demosthenes; in the chronology of reading, one first comes across these two mottos in the paratext, and they foreshadow essential elements of the novel. The first reads: "You will never wash out that stain; you cannot talk long enough for that"; then three questions follow: "Who wishes to speak? Who wishes to rake up old grievances? Who wishes to be answerable to the future?" (2009a: epigraph). Both quotations are from Demosthenes's very well-known "On the Crown," to which the novel repeatedly refers. The fact that Vásquez begins with what is probably the most important orator of antiquity as an an advocate or perhaps a symbol for the ubiquity of the Nazi horrors in the Colombian periphery illustrates the principle that he postulates in his poetics, namely that his "extraterritorial experience" (experiencia extraterritorial, 2009b: 188) as well as his universal engagement with literature have enriched the Colombian complex in the novel.

In the already-mentioned 2005 essay "Misunderstandings Surrounding Gabriel García Márquez,” Juan Gabriel Vásquez talks about García Márquez as a point of reference for his own writing:

How does one write in the shadow of One Hundred Years of Solitude? The question strikes me as a false problem, almost a rhetorical vacuity, and I have said so in more than one interview. But I'll now try to give my objections a less indignant and more rational, less informal and more articulate form. ${ }^{48}$

(Vásquez 2011b)

48 “ ¿Cómo se escribe bajo la sombra de Cien años de soledad? La pregunta me parece un falso problema, casi una vacuidad retórica, y lo he dicho más de una vez en más de una entrevista. Pero hoy intentaré dar a mis reparos un empaque menos indignado y más racional, menos informal y más articulado" (Vásquez 2005: 42). 
This connection probably has less to do with a Colombian bond between the two writers than with the Nobel Prize winner García Márquez's status as unquestionable within world literature, and here García Márquez may in fact be standing in for the entire Latin American Boom generation. The worldwide power of García Márquez's emblematic novel One Hundred Years of Solitude is closely intertwined with two fundamentally important pillars of the success of the Boom: first, literarily speaking, the successful staging of the project of a specifically Latin American search for identity, coupled with a formal dimension that allows the novel to be read as an epic; and second, in extra-literary terms, the Latin American writer's independence from the government, which was a new phenomenon, coupled with a leftist partisanship in the Sartrean sense, namely as a mouthpiece for the oppressed people. What this means, concretely, is that within the text there is a struggle for identity, preferably expressed using mythical elements like a cyclical understanding of time or special motifs like that of the mask. These elements are used to establish a collective identity that emphasizes the indigenous and the pre-Columbian, thus freeing itself from European hegemony. This emancipatory attempt is further amplified by the formal staging of the novel's contents, in that these motifs are integrated into "total novels" (novelas totales) and utopian projects. The combination of formal totality and the identity-creating moment makes it possible to read One Hundred Years of Solitude as an epic. The persuasiveness of this novel on the world literary scene (as is also the case for other Boom novels) therefore lies in the project, in other words in a specifically Latin American identity that is sought by way of recourse to a cultural essence (or origin).

In addition, as we saw in the first part of this chapter, in García Márquez's case, representing all of Latin American literature, a development was completed at the end of the 1960s that had already reached its climax at the turn of the century in Western Europe with what Pierre Bourdieu calls the autonomy of the literary field. The subsequent development of younger generations of Latin American writers - and in this case of Juan Gabriel Vásquez - is substantially related to the autonomy that the Boom generation achieved in the late 1960s.

Against this historical backdrop, the world literary significance of Vásquez's work can be repositioned and, at the same time, we can identify a new development in Latin American literatures in the context of world literary selection processes. The search for a specifically Latin American identity no longer seems to be the dominant reception filter. Vásquez's novels are less intent on utopia, less ideologically determined, less high-culture. Instead, we see a stronger expression of playfulness, parody, a mixture of high culture and everyday culture, and historical elements. In contrast to the earlier socially critical and utopian potential, the political dimension in Vásquez's work is less tendentious. 
In the 1960s, in the Latin American literatures that were called world literature, what was shown was a Latin American culture that fed (diachronically) on its own roots and was coherently shown from the inside, while any direct confrontation with the contemporary cultural Others, especially Europe and North America, was lacking; in Vásquez's work today, on the other hand, identity is thematized as an individual development that only emerges in the (synchronous) confrontation with the Other. Of all of his novels, El ruido de las cosas al caer (The Sound of Things Falling) most strongly conveys an alternative model of identity to that of García Márquez or of the Boom novels in general. The appeal to the memory of a specific period in Colombian history - the 1980s and, especially, 1990s, as a "post-violence" phase - enables a collective reading experience that owes its originality to the overlap between two phenomena. Initially, for non-Colombian readers, this is an extremely exoticist staging of life amid the phenomenon of drug trafficking, which among Colombian readers works as an identity-creating bond. But this bond of what begins as a national reception framework is then broken up by irony and an anecdotal tendency that allows it to become compatible with an internationally established pattern of world literary reading.

The awakening of a collective memory of a pre-Columbian past in One Hundred Years of Solitude is replaced by a very contemporary discourse of memory, that of the 1980s and 1990s:

People of my generation do these things: we ask each other what our lives were like at the moment of those events - almost all of which occurred in the 1980s - which defined or diverted them before we knew what was happening to us. ${ }^{49}$

Maya went back to remembering, back to the exhausting work of memory. ${ }^{50}$

(Vásquez 2012)

Thus, an old exoticism is replaced with a new one, one that achieves its place in world literature through internal textual dimensions.

\footnotetext{
49 "La gente de mi generación hace estas cosas: nos preguntamos cómo eran nuestras vidas al momento de aquellos sucesos, casi todos ocurridos durante los años ochenta, que las definieron o las desviaron sin que pudiéramos siquiera darnos cuenta de lo que nos estaba sucediendo" (Vásquez 2011a: 227).

50 "Maya volvió a recordar, volvió a dedicarse al fatigoso oficio de la memoria” (Vásquez 2011a: 244).
} 